\title{
Host Genetic Signatures of Susceptibility to Fungal Disease
}

\author{
Cláudia F. Campos, Frank L. van de Veerdonk, \\ Samuel M. Gonçalves, Cristina Cunha, Mihai G. Netea \\ and Agostinho Carvalho
}

\section{Contents}

1 Introduction: Genetic Regulation of the Host-Fungus Interaction

2 Pattern Recognition Receptors in Fungal Immunity

3 Genetic Defects in Pattern Recognition Receptors and Susceptibility

to Fungal Disease

3.1 Toll-like Receptors

3.2 C-Type Lectin Receptors

3.3 NOD-like and RIG-I-like Receptors

3.4 Soluble Pattern Recognition Receptors

4 Clinical Translation of Host Genetics in Medical Mycology

5 Conclusions

References

\begin{abstract}
Our relative inability to predict the development of fungal disease and its clinical outcome raises fundamental questions about its actual pathogenesis. Several clinical risk factors are described to predispose to fungal disease, particularly in immunocompromised and severely ill patients. However, these alone do not entirely explain why, under comparable clinical conditions, only some patients develop infection. Recent clinical and epidemiological studies have reported an expanding number of monogenic defects and common polymorphisms associated
\end{abstract}

\footnotetext{
C. F. Campos · S. M. Gonçalves · C. Cunha · A. Carvalho ( $\square)$

Life and Health Sciences Research Institute (ICVS), School of Medicine,

University of Minho, Campus de Gualtar, 4710-057 Braga, Portugal

e-mail: agostinhocarvalho@med.uminho.pt

C. F. Campos · S. M. Gonçalves · C. Cunha · A. Carvalho

ICVS/3B's-PT Government Associate Laboratory, Braga/Guimarães, Portugal

F. L. van de Veerdonk · M. G. Netea

Department of Internal Medicine and Radboud Center for Infectious Diseases (RCI),

Radboudumc, Nijmegen, The Netherlands
} 
with fungal disease. By directly implicating genetic variation in the functional regulation of immune mediators and interacting pathways, these studies have provided critical insights into the human immunobiology of fungal disease. Most of the common genetic defects reported were described or suggested to impair fungal recognition by the innate immune system. Here, we review common genetic variation in pattern recognition receptors and its impact on the immune response against the two major fungal pathogens Candida albicans and Aspergillus fumigatus. In addition, we discuss potential strategies and opportunities for the clinical translation of genetic information in the field of medical mycology. These approaches are expected to transfigure current clinical practice by unleashing an unprecedented ability to personalize prophylaxis, therapy and monitoring for fungal disease.

\section{Introduction: Genetic Regulation of the Host-Fungus Interaction}

An increasing number of fungal diseases has been documented over the past two decades. Although we are constantly exposed to fungi, only a few species can cause disease in healthy individuals. Opportunistic and otherwise commensal fungi can instead trigger life-threatening infections in individuals with acquired or treatment-induced immunodeficiencies, such as patients receiving hematopoietic stem-cell (HSCT) or solid organ (SOT) transplantation, or undergoing anticancer therapy (Pfaller and Diekema 2010). Many species of fungi are responsible for invasive infections, although more than $90 \%$ of all reported fungal-related deaths result from infection with species belonging to one of four genera: Candida, Aspergillus, Cryptococcus and Pneumocystis. These diseases are estimated to affect more than 2 million people annually and, in some cases, can have mortality rates that exceed 50\% (Brown et al. 2012).

Despite several clinical risk factors typically associated with fungal disease have been disclosed, the actual mechanisms underlying infection in the human host remain largely undefined. Like many infectious diseases, fungal infections are characterized by significant interindividual variability in their development, progression and resolution. While a significant contribution to infection might be credited to virulence traits and the ability of fungi to adapt to the human host, recent evidence has highlighted a dominant role of heritable factors (Cunha et al. 2013; Smeekens et al. 2013b; Wojtowicz and Bochud 2014). Our current understanding of the genetic basis of fungal disease has stemmed from the study of individuals with rare monogenic defects and from cohort-based studies to identify common polymorphisms associated with disease (Lionakis and Levitz 2017). In addition, mouse studies illustrating disparities in susceptibility to experimental infection between inbred strains have also strengthened the concept of genetic control of susceptibility to fungal disease (Durrant et al. 2011; Radovanovic et al. 2011). 
Clinical and basic research during the last decade has provided exciting new insights into the molecular and cellular players involved in the host-fungus interaction and antifungal host defense (Netea et al. 2015; van de Veerdonk et al. 2017). The improved understanding of the genetic mechanisms that regulate host immunity to fungi represents an opportunity for the development of new and more effective approaches to preventing and treating fungal diseases. In addition, future studies addressing the genetic architecture of both the host and the fungus and how it regulates the outcome of their interaction are expected to further support clinical translation and personalized medical interventions in fungal diseases (Oliveira-Coelho et al. 2015; Rello et al. 2018). In this review, we explore recent advances in the immunogenetics of fungal disease and how it modulates innate immunity to the two major fungal pathogens Candida albicans and Aspergillus fumigatus. Also discussed is how an improved understanding of the genetic regulation of the host-fungus interaction is expected to reform the clinical management of fungal disease by paving the way toward precision medical interventions based on individual host genetics.

\section{Pattern Recognition Receptors in Fungal Immunity}

Our understanding of innate immunity was revolutionized in the early 90 s with the groundbreaking concept of selective recognition of conserved pathogen-associated molecular patterns (PAMPs) by germline-encoded pattern recognition receptors (PRRs) (Takeuchi and Akira 2010). Although there are remarkable differences in the way different classes of pathogens are perceived by the immune system, the first step in developing a proper innate immune response is widely acknowledged to require fungal sensing by PRRs (Fig. 1). Owing to its inherent dynamic composition and variable cellular localization of the different constitutive components during the interaction with the host, the cell wall is considered the most abundant source of fungal PAMPs, such as $\beta$-1,3-glucans and mannans (Gow and Hube 2012; Latge et al. 2017).

The main families of PRRs include Toll-like receptors (TLRs), C-type lectin receptors (CLRs), nucleotide-binding oligomerization domain (NOD)-like receptors (NLRs) and retinoic acid-inducible gene-I (RIG-I)-like receptors (RLRs) (Netea et al. 2012). Following the recognition of their cognate ligands, PRRs induce mechanisms responsible for pathogen clearance, including the secretion of cytokines and chemokines, phagocytosis and production of reactive oxygen species (ROS), and orchestrate complex immunoregulatory processes resulting in the activation of adaptive immunity (Patin et al. 2018). The proficiency of fungal recognition and interaction with the membrane-associated PRRs also relies to a large extent on the opsonization by different families of soluble pattern recognition molecules, including collectins, pentraxins, ficolins and components of the complement pathway (Bidula and Schelenz 2016). Of note, studies have highlighted that these molecules may be exploited as a possible alternative or adjuvants to 


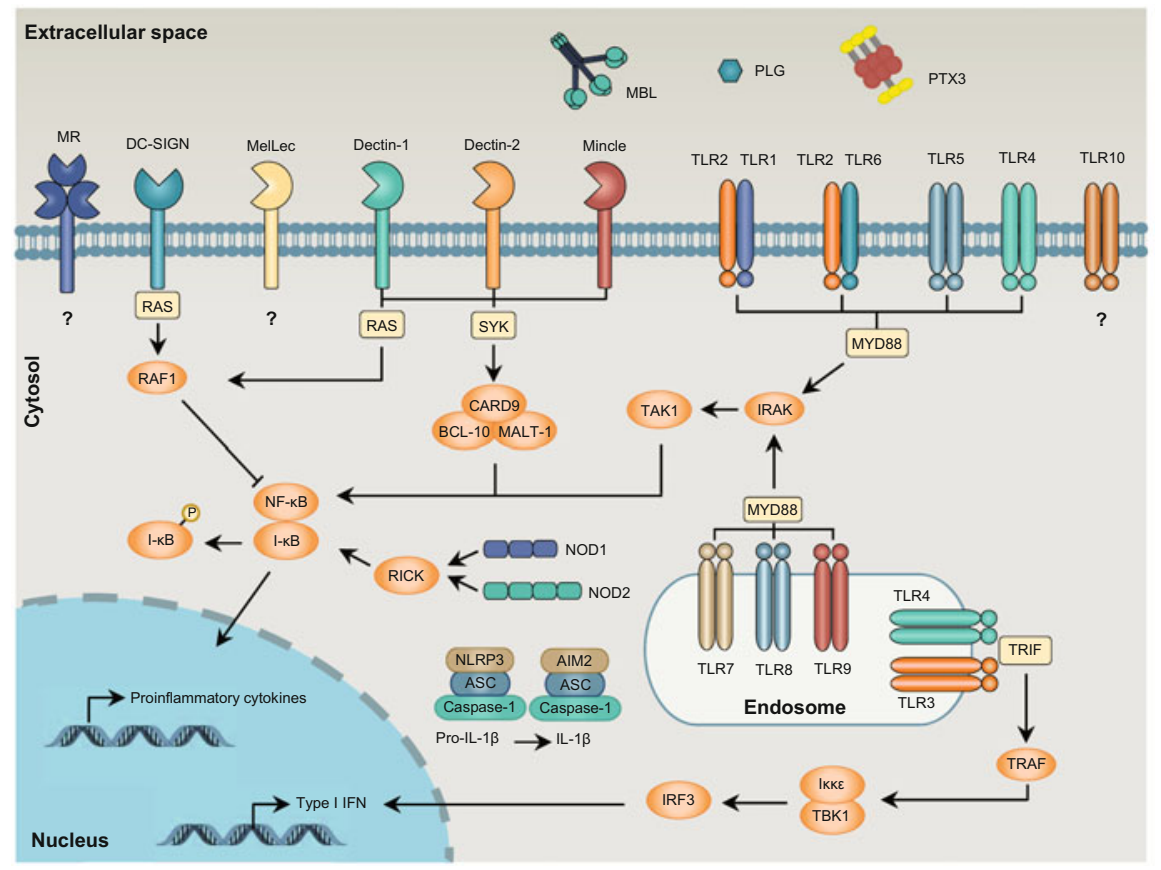

Fig. 1 Overview of PRRs and downstream signaling pathways. PRRs are expressed on the cell surface or are present in endosomes or the cytosol, where they detect PAMPs and activate downstream signaling pathways leading to the transcription of cytokines and chemokines, whereas soluble PRRs bind and opsonize fungi, facilitating their elimination. Upon stimulation, TLRs activate two disparate pathways that involve myeloid differentiation primary response protein 88 (MYD88) and/or TIR domain-containing adaptor protein inducing IFN- $\beta$ (TRIF). Crosstalk between TLR signaling cascades underlies the activation of different cellular processes, including the transcription of proinflammatory cytokines and chemokines, and type I IFN. On the other hand, CLRs trigger intracellular signaling pathways typically linked to the activation of the SYK kinase and CARD9, resulting in a cascade of downstream signaling and cellular activation that regulate and fine-tune NF- $\mathrm{KB}$ activation and cytokine gene expression. The stimulation of NLRs also regulates $\mathrm{NF}-\kappa \mathrm{B}$ activation via receptor-interacting protein-like interacting caspase-like apoptosis regulatory protein kinase (RICK), whereas the NLRP3 and AIM2 inflammasomes process bioactive proinflammatory cytokines, such as IL-1 $\beta$

currently available antifungal therapy to increase their efficacy (Lo Giudice et al. 2012; Marra et al. 2014). Besides pathogen-derived molecules, PRRs are also critically important in responding to products released from damaged host cells during infection, including nucleic acids, alarmins and metabolic products, collectively termed damage-associated molecular patterns (DAMPs) (Cunha et al. 2012). Regardless of the PRRs or soluble molecules implicated in fungal recognition or opsonization, the activation of antifungal immune responses requires a coordinated regulation of the function and cellular localization of individual or cooperating receptors. 
The role of TLRs in innate immunity was initially proposed following the observation that Drosophila lacking the hematocyte receptor Toll were extremely susceptible to infection with fungi and Gram-negative bacteria (Lemaitre et al. 1996). This discovery prompted the identification of mammalian TLRs shortly thereafter (Rock et al. 1998). Similar to other PRRs, TLRs are primarily expressed in cells of the immune system, including monocytes, neutrophils, basophils, eosinophils and natural killer cells, but also in cells of epithelial, endothelial and stromal origin (Netea et al. 2012). TLRs are characterized by containing extracellular domains with leucine-rich repeats that interact directly with PAMPs and cytoplasmic domains highly homologous to the sequences in the interleukin (IL)-1 and IL-18 receptors. After binding to their specific ligands, TLRs activate signaling cascades that promote the translocation of transcription factors to the nucleus, where they induce transcription of genes involved in inflammatory responses and mechanisms of pathogen clearance (Takeuchi and Akira 2010).

The large family of CLRs includes members such as dectin-1, dectin-2, mannose receptor, dendritic cell-specific intercellular adhesion molecule 3-grabbing non-integrin (DC-SIGN), macrophage inducible C-type lectin (Mincle), macrophage C-type lectin (MCL), and the recently identified MelLec (Brown et al. 2018). These receptors have carbohydrate recognition domains and bind microbial polysaccharides and, for this reason, they have been widely implicated in the activation and regulation of antifungal immune responses (Salazar and Brown 2018). Among CLRs, dectin-1 was the first to be identified and is currently the best described receptor able to orchestrate the activation of adaptive immune responses to fungi (Dambuza and Brown 2015). Dectin-1 recognizes $\beta$-glucans (Brown and Gordon 2001) and triggers intracellular signaling pathways that, synergistically and through cross-regulatory mechanisms, culminate in the activation of nuclear factor (NF)-KB and cytokine gene expression (Geijtenbeek and Gringhuis 2009). Although most of the CLR family members have been implicated in antifungal immunity in one way or another, the fungal ligands for most of them remain elusive. One exception was recently provided by the identification of MelLec as a specific receptor for 1,8-dihydroxynaphthalene (DHN)-melanin, a process required for eliciting protective immunity to A. fumigatus (Stappers et al. 2018). We also refer the reader to several excellent reviews on the biology of CLRs (Brown et al. 2018; Dambuza and Brown 2015; Salazar and Brown 2018).

Besides the mainly membrane-bound TLRs and CLRs, cytoplasmic PRRs are activated by pathogens following cell invasion or release of PAMPs into the cytoplasm. Although the fungal ligands that are recognized by NLRs have not been identified, their activation during infection results in the assembly of multimeric protein complexes named inflammasomes that are primarily responsible for converting inactive pro-IL-1 $\beta$ and pro-IL-18 into bioactive cytokines (van de Veerdonk et al. 2015). The NLR family pyrin domain containing 3 (NLRP3) and the NLR family CARD domain containing 4 (NLRC4) inflammasomes were specifically credited with a prominent role in the immune response to $C$. albicans (Borghi et al. 2015; Cheng et al. 2011; Hise et al. 2009; Tomalka et al. 2011). The NLRP3 and AIM2 inflammasomes were instead shown to form a dual cytoplasmic surveillance 
system that orchestrates protective immune responses against A. fumigatus (Karki et al. 2015). The contribution of NLRs to the immune response against fungi nonetheless extends beyond inflammasome formation. Fungal chitin has been demonstrated to dampen inflammatory responses to $C$. albicans by inducing the immunoregulatory cytokine IL-10 via the activation of NOD-containing receptor 2 (NOD2) and TLR9 (Wagener et al. 2014). More recently, NOD1 was found to play an inhibitory role in the host defense against A. fumigatus by suppressing dectin-1 expression and cytokine responses responsible for optimal fungal killing (Gresnigt et al. 2017). Taken together, these observations support the existence of highly dynamic regulatory mechanisms modulated by intracellular fungal recognition with important consequences to the overall antifungal immune response.

\section{Genetic Defects in Pattern Recognition Receptors and Susceptibility to Fungal Disease}

Genetic variation in the genes encoding PRRs can influence susceptibility to diseases caused by a wide range of fungal pathogens (Carvalho et al. 2010). As for most infectious diseases, genetic defects in the different families of PRRs have been widely linked with susceptibility to fungal disease (Netea et al. 2012). These associations highlight the complexity of the host genetic signatures influencing antifungal host defense. Here, we discuss the most relevant genetic variation in PRRs, its association with susceptibility to infection by Candida and Aspergillus, and their functional consequences to the activation of innate immune responses.

\subsection{Toll-like Receptors}

Following the early description of TLRs, genetic variation in these genes was proposed to underlie significant interindividual differences in susceptibility to infectious and inflammatory diseases (Netea et al. 2012). Although monogenic or primary immunodeficiencies affecting TLR signaling promote large effect sizes, this is typically a rare (or very rare) event on the general population that has not been implicated in the development of fungal disease thus far. However, TLRs are characterized by remarkable genetic diversity due to strong selective pressures during their evolution, particularly in the number of single nucleotide polymorphisms (SNPs) that lead to substitutions in amino acid residues (Quach et al. 2013). As such, before the advent of next-generation sequencing and genome-wide association studies, polymorphisms in TLRs were considered biologically plausible targets for involvement in susceptibility to infectious diseases, including fungal infections (Cunha et al. 2010b). Table 1 summarizes relevant genetic variants in TLRs and their association with susceptibility to infection by Candida and Aspergillus. 
Table 1 Genetic variation in TLRs and susceptibility to infection by Candida and Aspergillus

\begin{tabular}{l|l|l|l|l|l}
\hline $\begin{array}{l}\text { Gene } \\
(\mathrm{s})\end{array}$ & SNP(s) & $\begin{array}{l}\text { Nucleotide } \\
\text { change }\end{array}$ & $\begin{array}{l}\text { Amino } \\
\text { acid } \\
\text { change }\end{array}$ & Disease(s) & References \\
\hline TLR1 & rs5743611 & G $>$ C & R80T & IPA & Kesh et al. (2005) \\
\hline & rs4833095 & $\mathrm{C}>\mathrm{T}$ & N248S & IPA & Kesh et al. (2005) \\
\hline TLR2 & rs5743704 & $\mathrm{C}>\mathrm{A}$ & P631H & RVVC & Rosentul et al. (2014) \\
\hline TLR3 & rs3775296 & $\mathrm{G}>\mathrm{T}$ & - & IPA & Carvalho et al. (2012b) \\
\hline TLR4 & rs4986790 & $\mathrm{A}>\mathrm{G}$ & D299G & $\begin{array}{l}\text { IPA and } \\
\text { CPA }\end{array}$ & $\begin{array}{l}\text { Bochud et al. (2008), Carvalho } \\
\text { et al. (2008), de Boer et al. (2011), } \\
\text { Koldehoff et al. (2013) }\end{array}$ \\
\hline TLR5 & rs5744168 & $\mathrm{C}>\mathrm{T}$ & R392X & IPA & $\begin{array}{l}\text { Bochud et al. (2008), Koldehoff } \\
\text { et al. (2013) }\end{array}$ \\
\hline TLR6 & rs5743810 & $\mathrm{C}>\mathrm{T}$ & S249P & IPA & Krube et al. (2013) \\
\hline TLR9 & rs5743836 & $\mathrm{C}>\mathrm{T}$ & - & ABPA & Carvalho et al. (2008) \\
\hline
\end{tabular}

The first nucleotide (and corresponding amino acid) is the ancestral nucleotide and therefore is considered the wild-type allele. SNP single nucleotide polymorphism; IPA invasive pulmonary aspergillosis; $R V V C$ recurrent vulvovaginal candidiasis; $C P A$ chronic pulmonary aspergillosis; $A B P A$ allergic bronchopulmonary aspergillosis

The TLR4 sequence variants rs4986790 (D299G) and rs4986791 (T399I) constitute an haplotype that has been reported to alter the leucine-rich repeat region of the receptor and decrease the efficiency of ligand recognition (Arbour et al. 2000). The presence of this haplotype in donors of allogeneic HSCT was associated with the development of invasive pulmonary aspergillosis (IPA) in the corresponding patients (Bochud et al. 2008). Although this association was validated in independent HSCT cohorts (de Boer et al. 2011; Koldehoff et al. 2013) and in immunocompetent individuals suffering from chronic aspergillosis (Carvalho et al. 2008), other studies have failed to replicate the findings (Carvalho et al. 2009; Fisher et al. 2017; Kesh et al. 2005). The TLR4 haplotype was reported to delay immune reconstitution after transplant (Koldehoff et al. 2013), and this could represent a key mechanism justifying its association with IPA in specific patient populations. The exact mechanism by which TLR4 variants may influence antifungal immune responses remains however unknown - particularly since no fungal ligands (or endogenous molecules released during infection) have been identified to date - and this may also support the lack of association with other fungal diseases, including candidemia (Plantinga et al. 2012).

Genetic variation in TLRs other than TLR4 has also been proposed as an important risk factor for fungal disease. Earlier studies have reported associations of the polymorphisms rs5743611 (R80T) and rs4833095 (N248S) in TLR1 and rs5743810 (S249P) in TLR6 with IPA (Kesh et al. 2005), but only TLR6 has been shown to be required for the human immune response to A. fumigatus (Rubino et al. 2012). TLR1 also appears to be an important repository of genetic variability 
increasing susceptibility to candidemia (Plantinga et al. 2012). Although the precise mechanism(s) whereby TLR1 influences the risk of candidemia remains elusive, the variant rs5743618 (I602S) has been shown to impair the trafficking of TLR1 to the cell surface and to result in decreased NF- $\kappa \mathrm{B}$ activation and proinflammatory cytokine responses to TLR1 agonists (Johnson et al. 2007; Wurfel et al. 2008). In addition, and despite it was not associated with systemic Candida infection (Plantinga et al. 2012), the rs5743704 (P631H) SNP in TLR2 was implicated in the development of idiopathic recurrent vulvovaginal candidiasis (RVVC) (Rosentul et al. 2014). Finally, the variant rs5743836 in the promoter of TLR9 was associated with the development of allergic bronchopulmonary aspergillosis (ABPA) (Carvalho et al. 2008), although this study still requires confirmation.

Another interesting example regards TLR5, the receptor for flagellin expressed by flagellated bacteria (Hayashi et al. 2001), and in which a SNP leading to an early stop codon (R392X) has been shown to disrupt flagellin recognition (Hawn et al. 2003). In HSCT recipients, the presence of this variant was associated with the development of IPA (Grube et al. 2013), thereby suggesting a likely important antifungal function of TLR5 in the non-hematopoietic compartment. However, functional data is not available, and additional studies are warranted to identify the so far unsuspected mechanisms (and the ligand) by which TLR5 might influence susceptibility to IPA. In any case, the fact that R392X presents with a relatively common frequency without imposing a primary immunodeficiency phenotype suggests a non-essential role for TLR5 in host defense (Wlasiuk et al. 2009).

Despite classically acknowledged as a prototypical receptor for double stranded RNA (Zhang et al. 2013), TLR3 has been implicated in fungal recognition and activation of adaptive immune responses. In particular, the regulatory variant rs3775296 in TLR3 was demonstrated to increase the risk of IPA after HSCT (Carvalho et al. 2012b). Cross-presenting dendritic cells harboring this variant displayed an impaired expression of TLR3 and sensing of fungal RNA, which ultimately resulted in the defective priming of memory CD8(+) T-cell responses to A. fumigatus. This study was recently supported by evidence demonstrating a similar association with severe asthma with fungal sensitization (Overton et al. 2017). Although there is no evidence implicating this regulatory variant in susceptibility to infections by Candida, the non-synonymous SNP rs3775291 (L412F) in TLR3 was however detected more frequently in patients suffering from chronic mucocutaneous candidiasis (CMC) (Nahum et al. 2011).

This study represents a critical example of how genetic defects in TLRs (and other PRRs) may influence adaptive immune responses, in addition to fungal sensing and innate immunity. Although this has yet to be addressed, there is an unequivocal need to consider the genetic profile of the patient during diagnostic approaches based on the measurement of fungal-specific adaptive immune responses (Koehler et al. 2018; Potenza et al. 2013). The same applies to immunotherapeutic strategies focused on the direct or indirect manipulation of cytokines, since there are many examples of genetic variants that influence cytokine production and function (Cunha et al. 2017; Johnson et al. 2012). In conclusion, the success of novel diagnostic and immunotherapeutic approaches for fungal diseases 
will only be possible if guided by personalization based on the interindividual variability in immune function, particularly for genetic variants with well-established functional consequences.

\section{$3.2 \quad$ C-Type Lectin Receptors}

Given the well-established role of CLRs in the coordination of antifungal immune responses, their genetic variation has been extensively implicated in susceptibility to fungal disease (Table 2). The importance of dectin-1 in the recognition of $\beta$-glucan and activation of antifungal immunity has been demonstrated in mouse studies but also in patients with recurrent fungal infections carrying the early stop codon polymorphism rs16910526 (Y238X) (Ferwerda et al. 2009; Taylor et al. 2007). This variant results in a truncated form of dectin-1 lacking several amino acids within the carbohydrate recognition domain, which underlies its decreased expression at the surface of myeloid cells and a defective production of cytokines, particularly IL-17, after stimulation with $\beta$-glucan or $C$. albicans (Ferwerda et al. 2009). Following the initial identification of Y238X, and given its specific impact on the activation of Th17-mediated immunity, it has since been vastly implicated in mucosal and gastrointestinal fungal colonization (De Luca et al. 2013; Plantinga et al. 2009; Usluogullari et al. 2014). This functional axis is further demonstrated by primary immunodeficiencies due to rare mutations in STAT3, IL-17RA and IL-17F that impair Th17 immunity and are associated with CMC and aspergillosis (Lionakis and Levitz 2018). Because the cellular localization of the different dectin-1 isoforms regulates the signaling quality of antifungal immunity (Carvalho et al. 2012c; Fischer et al. 2017), it is also tempting to speculate that this may be one additional mechanism through which the Y238X variant may contribute to infection. Of note, another non-synonymous variant in dectin-1 (rs16910527; I223S) was instead associated with lower levels of interferon (IFN)- $\gamma$ and the risk of oropharyngeal candidiasis in HIV patients (Plantinga et al. 2010). This suggests that different pathogenetic mechanisms are likely in place depending on the specific structural consequences of genetic variants to dectin-1 function.

Although the clinical phenotype of patients carrying the dectin-1 stop codon is relatively mild and less severe than that of patients with classic CMC (Puel et al. 2010), the Y238X variant was found to strongly predispose HSCT recipients to the development of IPA (Chai et al. 2011; Cunha et al. 2010a). Additional variants in dectin-1, but also dectin-2 and DC-SIGN (CD209), were likewise correlated with the development of IPA in hematological patients (Fischer et al. 2016; Sainz et al. 2012). Importantly, the genetic deficiency of dectin-1 in both the hematopoietic and non-hematopoietic compartments was disclosed to synergize towards risk of infection (Cunha et al. 2010a), a finding that was validated in the largest HSCT patient cohort at-risk of IPA collected to date (Fisher et al. 2017) and that highlights the key role of dectin-1 in antifungal immunity across multiple cell types. Among the many biological processes that are regulated by dectin-1 in response to fungi, 
Table 2 Genetic variation in CLRs and susceptibility to infection by Candida and Aspergillus

\begin{tabular}{|c|c|c|c|c|c|}
\hline Gene(s) & $\mathrm{SNP}(\mathrm{s})$ & $\begin{array}{l}\text { Nucleotide } \\
\text { change }\end{array}$ & $\begin{array}{l}\text { Amino } \\
\text { acid } \\
\text { change }\end{array}$ & Disease(s) & References \\
\hline CARD9 & rs 4077515 & $\mathrm{G}>\mathrm{A}$ & S12N & ABPA & $\mathrm{Xu}$ et al. (2018) \\
\hline \multirow[t]{4}{*}{$C D 209$} & rs4804800 & $\mathrm{G}>\mathrm{A}$ & - & IPA & Sainz et al. (2012) \\
\hline & rs11465384 & $\mathrm{C}>\mathrm{T}$ & - & IPA & Sainz et al. (2012) \\
\hline & rs7248637 & $A>G$ & - & IPA & Sainz et al. (2012) \\
\hline & rs7252229 & $\mathrm{C}>\mathrm{G}$ & - & IPA & Sainz et al. (2012) \\
\hline CLEC1A & rs2306894 & $\mathrm{C}>\mathrm{G}$ & G26A & IPA & Stappers et al. (2018) \\
\hline \multirow[t]{4}{*}{ CLEC7A } & rs16910526 & $\mathrm{T}>\mathrm{G}$ & Y238X & $\begin{array}{l}\text { Candida } \\
\text { colonization, } \\
\text { RVVC and IPA }\end{array}$ & $\begin{array}{l}\text { Chai et al. (2011), Cunha } \\
\text { et al. (2010a), De Luca } \\
\text { et al. (2013), Fisher et al. } \\
\text { (2017), Plantinga et al. } \\
\text { (2009), Usluogullari et al. } \\
\text { (2014) }\end{array}$ \\
\hline & rs16910527 & $\mathrm{A}>\mathrm{C}$ & I223S & $\begin{array}{l}\text { Oropharyngeal } \\
\text { candidiasis }\end{array}$ & Plantinga et al. (2010) \\
\hline & rs7309123 & $\mathrm{G}>\mathrm{C}$ & - & IPA & $\begin{array}{l}\text { Fischer et al. (2016), } \\
\text { Sainz et al. (2012) }\end{array}$ \\
\hline & rs3901533 & $\mathrm{G}>\mathrm{T}$ & - & IPA & Sainz et al. (2012) \\
\hline
\end{tabular}

The first nucleotide (and corresponding amino acid) is the ancestral nucleotide and therefore is considered the wild-type allele. SNP single nucleotide polymorphism; $A B P A$ allergic bronchopulmonary aspergillosis; IPA invasive pulmonary aspergillosis; $R V V C$ recurrent vulvovaginal candidiasis

the production of ROS through the NADPH oxidase system and the activation of downstream clearance mechanisms is critically important, as reflected by the extreme susceptibility of patients with chronic granulomatous disease (CGD) to aspergillosis (Grimm et al. 2013; Kyrmizi et al. 2013). The role of dectin-1 in immunity to infection may however extend beyond the immediate activation of antifungal effector mechanisms. For example, recognition of $\beta$-glucan has been demonstrated to confer innate immune memory to infection - a process referred to as trained immunity (Netea and van der Meer 2017) - by regulating multiple processes of cellular metabolism (Arts et al. 2016; Bekkering et al. 2018; Cheng et al. 2014). In the future, it will be critical to assess the extent to which the Y238X variant predisposes to fungal disease by impairing the induction of "natural" trained immunity as the result of our constant exposure to fungi.

Mutations in caspase recruitment domain-containing protein 9 (CARD9), the adaptor molecule that transduces signals from dectin-1 and other CLRs, have been identified in patients suffering from mucocutaneous fungal infections (Glocker et al. 2009). Importantly, neutrophils from CARD9-deficient patients were found to display impaired phagolysosomal killing of unopsonized C. albicans, a phenotype that was independent of dectin-1 and NADPH oxidase activity, thereby explaining the variable clinical presentation of fungal infection in patients suffering from 
dectin-1 and CARD9 deficiency and CGD (Gazendam et al. 2014). Human CARD9 deficiency was also found to predispose to extrapulmonary aspergillosis with sparing of the lungs through a mechanism involving the defective accumulation of neutrophils in infected tissue (Rieber et al. 2016). Of note, the common polymorphism rs4077515 (S12N) in CARD9 was recently implicated in the risk of ABPA (Xu et al. 2018). Mechanistically, work performed in knock-in mice expressing the mutated form of human CARD9 revealed the remarkable contribution of S12N to the activation of NF- $\mathrm{KB}$ subunit RelB, which in turn promoted the production of IL-5 in alveolar macrophages and the recruitment of eosinophils to drive Th2 cell-mediated allergic responses. Given the key role of CARD9 in orchestrating the signals collected from the different CLRs, it will be interesting to assess whether this or other common genetic variants may impact susceptibility to other forms of aspergillosis and eventually other fungal infections.

MelLec (encoded by the CLEC1A gene) was recently characterized as the functional receptor for DHN-melanin from A. fumigatus (Stappers et al. 2018). This discovery was accompanied by the identification of a non-synonymous variant rs2306894 (G26A) in the cytoplasmic tail of MelLec, suggesting an influence on intracellular signal transduction rather than on the recognition of DHN-melanin. Accordingly, the presence of G26A in HSCT donors was found to strongly increase the risk of IPA in the corresponding recipient as the result of a broad defect in cytokine production by myeloid cells (Stappers et al. 2018). Although there is still much to be learned about the mechanisms through which MelLec orchestrates the immune response against A. fumigatus (Casadevall 2018), these findings demonstrate the key role of myeloid-expressed MelLec and its genetic variation to the human host defense against $A$. fumigatus.

\subsection{NOD-like and RIG-I-like Receptors}

Apart from the involvement of NLRs in inflammasome formation, the function of canonical receptors such as NOD1 and NOD2 in the host defense against fungi remained until recently poorly studied. Several polymorphisms in NOD1 and NOD2 have been typically associated with the development of many infectious and inflammatory diseases, namely Crohn's disease (Caruso et al. 2014), but not fungal infections. A recent genetic screening in HSCT patients and corresponding donors revealed however that the donor rs2066842 (P268S) variant was associated with protection from IPA (Gresnigt et al. 2018). Mechanistically, mononuclear cells harboring this variant displayed enhanced phagocytosis and killing capacity whereas NOD2 activation instead reduced the antifungal potential of these cells. Further supporting the suppressive effect of NOD2 activation on antifungal effector functions, NOD2 deficiency conferred resistance to experimental aspergillosis in a mouse model of infection. Altogether, the P268S variants in NOD2 represents one of the few available examples associated with genetically-determined protection 
Table 3 Genetic variation in NLRs and RLRs and susceptibility to infection by Candida and Aspergillus

\begin{tabular}{l|l|l|l|l|l}
\hline $\begin{array}{l}\text { Gene } \\
(\mathrm{s})\end{array}$ & SNP(s) & $\begin{array}{l}\text { Nucleotide } \\
\text { change }\end{array}$ & $\begin{array}{l}\text { Amino acid } \\
\text { change }\end{array}$ & Disease(s) & References \\
\hline NLRP3 & rs74163773 & $\begin{array}{l}12,9,7,6 \\
\text { VNTR }\end{array}$ & - & RVVC & $\begin{array}{l}\text { Jaeger et al. (2016), } \\
\text { Lev-Sagie et al. (2009) }\end{array}$ \\
\hline NOD2 & rs2066842 & $\mathrm{C}>\mathrm{T}$ & P268S & IPA & Gresnigt et al. (2018) \\
\hline IFIH1 & rs3747517 & $\mathrm{G}>\mathrm{A}$ & H843R & Candidemia & Jaeger et al. (2015) \\
\hline & rs1990760 & $\mathrm{C}>\mathrm{T}$ & A946T & Candidemia & Jaeger et al. (2015) \\
\hline
\end{tabular}

The first nucleotide (and corresponding amino acid) is the ancestral nucleotide and therefore is considered the wild-type allele. SNP single nucleotide polymorphism; VNTR variable number of tandem repeats; $R V V C$ recurrent vulvovaginal candidiasis; IPA invasive pulmonary aspergillosis

from fungal infection and highlights the interesting possibility to block NOD2 signaling as a therapeutic intervention in IPA.

There is an intricate relationship between dectin-1 signaling and inflammasome formation in response to both C. albicans and A. fumigatus (Cheng et al. 2011; Said-Sadier et al. 2010). The variable number of tandem repeats (VNTR) rs74163773 in intron 4 of NLRP3 was reported to be more frequently detected in women suffering from RVVC (Lev-Sagie et al. 2009), a finding that was recently validated in a larger multicenter cohort (Jaeger et al. 2016). Importantly, both studies demonstrated that the levels of IL-1 $\beta$ were influenced by the number of intronic repeats carried by the patients, suggesting a regulatory role of this VNTR on NLRP3 inflammasome activity.

An important role in host defense against $C$. albicans has also been ascribed to genetic variants in other cytosolic receptors, namely RLRs. In particular, the missense variants rs1990760 (A946T) and rs3747517 (H843R) in MDA5 (IFIH1) were shown to be associated with systemic Candida infection as the result of an altered cytokine response (Jaeger et al. 2015). Like TLR3, this receptor for viral RNA also showed unsuspected effects in antifungal immunity, thereby suggesting intracellular receptors for fungal nucleic acids as novel targets amenable to therapeutic manipulation. Table 3 illustrates relevant genetic variants in NLRs and RLRs associated with fungal disease.

\subsection{Soluble Pattern Recognition Receptors}

In addition to the membrane-bound PRRs discussed in detail above, there are several soluble molecules that are endowed with the ability to interact with and bind to microbial polysaccharides without transducing intracellular signals and that function as opsonins to facilitate phagocytosis (Bidula and Schelenz 2016). Table 4 summarizes relevant genetic variants in soluble PRRs and their association with susceptibility to fungal disease. The mannose-binding lectin (MBL), a CLR that 
Table 4 Genetic variation in soluble PRRs and susceptibility to infection by Candida and Aspergillus

\begin{tabular}{|c|c|c|c|c|c|}
\hline $\begin{array}{l}\text { Gene } \\
\text { (s) }\end{array}$ & $\mathrm{SNP}(\mathrm{s})$ & $\begin{array}{l}\text { Nucleotide } \\
\text { change }\end{array}$ & $\begin{array}{l}\text { Amino } \\
\text { acid } \\
\text { change }\end{array}$ & Disease(s) & References \\
\hline \multirow[t]{2}{*}{$M B L 2$} & rs5030737 & $\mathrm{C}>\mathrm{T}$ & R52C & $\mathrm{CPA}$ & $\begin{array}{l}\text { Crosdale et al. (2001), Vaid } \\
\text { et al. (2007) }\end{array}$ \\
\hline & rs 1800450 & $\mathrm{G}>\mathrm{A}$ & G54D & RVVC & $\begin{array}{l}\text { Babula et al. (2003), Donders } \\
\text { et al. (2008), Giraldo et al. } \\
\text { (2007), Nedovic et al. (2014), } \\
\text { Wojitani et al. (2012) }\end{array}$ \\
\hline$P L G$ & rs 4252125 & $A>G$ & D472N & IPA & Zaas et al. (2008) \\
\hline \multirow[t]{3}{*}{ PTX3 } & rs2305619 & $\mathrm{A}>\mathrm{G}$ & - & IPA & $\begin{array}{l}\text { Cunha et al. }(2014,2015), \\
\text { Fisher et al. }(2017)\end{array}$ \\
\hline & rs 3816527 & $\mathrm{~A}>\mathrm{C}$ & A48D & $\begin{array}{l}\text { IPA and } \\
\text { mold } \\
\text { infection and } \\
\text { colonization }\end{array}$ & $\begin{array}{l}\text { Cunha et al. }(2014,2015) \text {, } \\
\text { Wojtowicz et al. (2015) }\end{array}$ \\
\hline & rs 1840680 & $\mathrm{G}>\mathrm{A}$ & - & $\begin{array}{l}\text { IPA and } \\
\text { CPA }\end{array}$ & $\begin{array}{l}\text { Cunha et al. (2014), He et al. } \\
\text { (2018) }\end{array}$ \\
\hline
\end{tabular}

The first nucleotide (and corresponding amino acid) is the ancestral nucleotide and therefore is considered the wild-type allele. SNP single nucleotide polymorphism; $C P A$ chronic pulmonary aspergillosis; $R V V C$ recurrent vulvovaginal candidiasis; IPA invasive pulmonary aspergillosis

binds carbohydrate patterns from microorganisms and activates the lectin pathway of the complement system, stands out as one of the most well-known examples (Foo et al. 2015). Many studies have established genetic variation to be a major regulator of the levels and function of $\mathrm{MBL}$ in as much as $8 \%$ of individuals in the general population (Sprong and van Deuren 2008). Interestingly, these individuals do not display any obvious clinical phenotypes, suggesting that MBL deficiency may be, to a large extent, compensated by the redundancy of the humoral innate immune system, namely by the vast set of molecules that possess similar opsonic properties. Although not presenting as an outright immunodeficiency, the genetically-determined defect in the function of MBL is acknowledged as an important risk factor for infection, particularly in immunocompromised hosts. There are several known combinations of non-synonymous and promoter variants in the gene encoding MBL, either affecting the expression levels, its functional activity or both (Carvalho et al. 2010). Several studies have proposed a role for the rs1800450 (G54D) variant in MBL in the development of RVVC (Babula et al. 2003; Donders et al. 2008; Giraldo et al. 2007; Wojitani et al. 2012), and this was recently confirmed in a meta-analysis (Nedovic et al. 2014). In addition, the levels of circulating MBL were found to vary significantly during the course of invasive candidiasis (Damiens et al. 2012), although the extent to which genetic variation regulated this phenotype was not assessed. The same holds true for IPA, in which low circulating concentrations of $\mathrm{MBL}$ were detected in infected patients (Lambourne et al. 2009). Although there is no evidence for a contribution of genetic 
variants in MBL to invasive disease, the development of chronic pulmonary aspergillosis was nonetheless linked with the presence of variable MBL alleles at codon 52 (Crosdale et al. 2001; Vaid et al. 2007). Because most of the studies that have addressed genetic variation in MBL and risk of fungal disease in the past were flawed by the limited number of patients analyzed, these associations need to be revisited in larger and well-characterized cohorts.

Another soluble PRR that has received a great deal of attention in the field of fungal diseases in the past is the long pentraxin-3 (PTX3) (Foo et al. 2015). This molecule has been shown to bind microbial moieties from a wide range of microorganisms, including bacteria, viruses, and fungi, particularly A. fumigatus (Garlanda et al. 2002). Although classic immunodeficiencies have not been linked to PTX3 deficiency, common polymorphisms have been disclosed as important risk factors across different infectious diseases, namely Pseudomonas aeruginosa colonization in cystic fibrosis patients (Chiarini et al. 2010) and urinary tract infections (Jaillon et al. 2014). Remarkably, and according to its nonredundant role in immunity to A. fumigatus in mouse models of infection (Garlanda et al. 2002), genetic variation in PTX3 was identified as a major risk factor for IPA after HSCT (Cunha et al. 2014). These findings were validated in a large, independent study (Fisher et al. 2017) and extended across different clinical settings, including solid organ transplant recipients (Cunha et al. 2015; Wojtowicz et al. 2015) and patients with chronic obstructive pulmonary disease (Cunha and Carvalho 2018; He et al. 2018). Collectively, these studies highlight genetic variation in PTX3 as robust host-derived markers for IPA and lay the foundations for well-designed clinical trials assessing their validity in the clinical setting.

Earlier studies have suggested binding of galactomannan to PTX3 (Garlanda et al. 2002). However, definitive evidence about the actual fungal ligand recognized by PTX3 is still lacking. This is in line with reports showing binding of PTX3 to the cell wall of $C$. albicans (Tierney et al. 2012), although no studies have been performed to date exploring the contribution of genetic variation in PTX3 to the risk of infections caused by Candida. Whatever the ligand(s) involved, PTX3 deficiency was found to hamper the normal alveolar expression of the protein and, at a cellular level, it impaired the antifungal effector mechanisms of neutrophils, namely phagocytosis and killing (Cunha et al. 2014). The specific impact of PTX3 deficiency on neutrophil function was corroborated by the loss of the genetic association in patients that developed IPA during severe neutropenia. However, additional mechanisms of antifungal host defense may also be influenced by PTX3 deficiency. The recent demonstration that PTX3 is a critical molecule bridging neutrophil function and B-cell function, namely class switching, plasmablast expansion and antibody production, represents one such example (Chorny et al. 2016). In addition, binding of PTX3 to myeloid differentiation protein 2, an adapter of the TLR4 signaling complex, is critically required for immune protection in experimental aspergillosis (Bozza et al. 2014). This raises the interesting possibility that the combined genetic deficiency of PTX3 and TLR4 might underlie a higher risk of IPA than the single defects alone, a hypothesis that requires confirmation. 
The measurement of PTX3 in the bronchoalveolar fluids of mechanically ventilated patients was recently proposed to be endowed with the ability to identify microbiologically confirmed pneumonia (Mauri et al. 2014). The alveolar concentrations of PTX3 are known be determined at the genetic level (Cunha et al. 2014), and, as such, one could expect a further improvement to the diagnostic performance of PTX3 by knowing in advance the genotypic profile of the patient. In addition, PTX3 deficiency was also shown to influence the levels of alveolar cytokines in hematological patients suffering from IPA and to impact their ability in discriminating infection (Gonçalves et al. 2017). More important, reinstating the normal levels of PTX3 in vitro with the recombinant protein was sufficient to restore the efficacy of the antifungal effector functions of neutrophils (Cunha et al. 2014). Although data in the clinical setting is so far lacking, these observations support the potential applicability of PTX3 in novel prophylactic or therapeutic approaches for IPA in patients at-risk (Carvalho et al. 2012a). As stated above, the combined use of antifungal therapy and PTX3 treatment has been found to improve the efficacy of the drug alone in animal models of IPA (Lo Giudice et al. 2012; Marra et al. 2014).

Another example of a soluble PRR characterized by relevant genetic diversity regards plasminogen. By mining genetic data obtained from an unbiased screen of survival data in different strains of mice subjected to experimental aspergillosis, the non-synonymous variant rs4252125 (D472N) was correlated with the risk of IPA in patients undergoing HSCT (Zaas et al. 2008). These findings support the importance of additional pre-clinical studies testing different models of infection and evaluating additional immune-related readouts to assist in the discovery of human genetic variation with an important contribution to the risk of infection.

\section{Clinical Translation of Host Genetics in Medical Mycology}

Many studies over the past decade have implicated genetic variation in PRRs in the risk of developing fungal disease, particularly under predisposing clinical conditions such as those in the hematology setting (Cunha et al. 2011b; van der Velden et al. 2011). However, a great deal of work is still required to identify the actual causative alleles and their functional consequences, as well as to precisely pinpoint the biological mechanisms through which these influence the risk of infection. We have currently a large amount of genetic links to susceptibility to fungal disease at our disposal; however, clinical data supporting the translation of these critical insights into improved patient outcomes has been practically inexistent (Cunha et al. 2011a). This can be largely attributed to the relatively small effect size of the identified variants (since many carriers will not develop infection), which may negatively influence the discriminatory ability of the genetic profile to inform clinical decision-making. Although this limitation will hardly be countered soon 
and the use of genetic information to predict the risk of fungal disease is unlikely to alter clinical practice in the near future, the predictive performance of the genetic information may benefit from advanced genetic screening strategies and mathematical models. The integration of host and pathogen genetic data into stratification models that also consider the clinical characteristics of the patients are expected to improve our current ability to predict risk and progression of disease, including the response to treatment and its duration, and adverse events. A first, modest step toward this goal was recently taken in a study that demonstrated that the concerted analysis of selected genetic and clinical factors into a predictive model could be used to guide preemptive therapy in hematological patients (White et al. 2018).

Although genetic data in the clinical setting has historically been investigated with the goal to develop risk stratification and diagnostic strategies, recent studies illustrating how genetic variation regulates processes of host immunity raises the exciting possibility that it may also be exploited to guide immunotherapy. Most of the clinical trials performed to date have failed to account for the significant impact that genetic variation may pose on subgroups of individuals, and this may partly explain the disappointing outcomes of trials involving anti-inflammatory agents for the treatment of sepsis (Cohen et al. 2015). There is therefore an urgent need to identify and characterize relevant genetic variation in the stratification of patients enrolled in clinical trials of immunomodulatory agents (Rello et al. 2018).

The application of next-generation sequencing and systems biology approaches provide a powerful tool to identify essential genes and pathways in the host-fungus interaction at a level of complexity that was not possible beforehand (Dix et al. 2016). Although in the field of fungal diseases, genetic association studies at the genome-wide level are scarce, a few examples exist which have enabled the identification of novel players controlling susceptibility to infection (Kumar et al. 2014; Smeekens et al. 2013a). For example, the integration of transcriptional data and functional genomics revealed an unanticipated role of type I IFN in the host defense against Candida (Smeekens et al. 2013a). Polymorphisms in type I IFN genes were found to modulate cytokine production and to drive a skew from a Th17 to a Th1 type of response, thereby predisposing to candidemia in critically ill patients. More recently, other functional genomics approaches combining whole genome information and immunological screenings have also provided invaluable evidence about the genetic regulation of cytokine production in humans in response to different stimuli, including fungi (Li et al. 2016a, b). By correlating genome-wide SNP genotypes with cytokine abundance in response to fungal stimulation, several cytokine quantitative trait loci (QTL), i.e., genetic variants that control cytokine production, were identified ( $\mathrm{Li}$ et al. 2016a). Among them, a cytokine QTL at the NAA35/GOLM1 locus markedly influenced the levels of IL-6 produced and was associated with susceptibility to candidemia. Altogether, these studies support the need to consider the genetic contribution to immune phenotypic variation (e.g., cytokine production and immune cell function) to generate accurate maps of the human genomic architecture regulating susceptibility to fungal disease. 


\section{Conclusions}

Our current understanding of the immunobiology of human fungal diseases has derived largely from studies addressing polygenic susceptibility. These studies have not only revealed the individual contribution of genetic variants but have also highlighted the complex interactions between adding effects of variants with small or modest effect sizes to the immune response. The current state-of-the-art is however not adequate for the needs of clinicians since it does not allow the accurate prediction of which individuals might develop fungal disease or that may benefit the most from intensive diagnostic surveillance or alternative prophylaxis and treatment strategies. Clinical translation of patient genetics will benefit from the concerted action of clinicians and researchers into the establishment of larger and well-characterized patient cohorts, as well as comprehensive functional testing to identify the biological mechanisms of association with infection. By unraveling molecules and pathways whose expression or function may be regulated at the genetic level may allow the possibility to target them with personalized immunotherapeutics aimed at restoring lacking or defective immune components (Cunha and Carvalho 2012). In conclusion, an improved understanding of how specific genetic signatures regulate susceptibility to fungal disease may revolutionize the field of medical mycology, opening new horizons and laying the foundations for personalized medical interventions based on individual genomics in patients who are at risk.

Acknowledgements This work was supported by the Northern Portugal Regional Operational Programme (NORTE 2020), under the Portugal 2020 Partnership Agreement, through the European Regional Development Fund (FEDER) (NORTE-01-0145-FEDER-000013), the Fundação para a Ciência e Tecnologia (FCT) (IF/00735/2014 to AC, and SFRH/BPD/96176/2013 to CC), the Institut Mérieux (Mérieux Research Grant 2017 to CC), and the European Society of Clinical Microbiology and Infectious Diseases (ESCMID Research Grant 2017 to AC).

\section{References}

Arbour NC, Lorenz E, Schutte BC, Zabner J, Kline JN, Jones M, Frees K, Watt JL, Schwartz DA (2000) TLR4 mutations are associated with endotoxin hyporesponsiveness in humans. Nat Genet 25(2):187-191. https://doi.org/10.1038/76048

Arts RJ, Novakovic B, Ter Horst R, Carvalho A, Bekkering S, Lachmandas E, Rodrigues F, Silvestre R, Cheng SC, Wang SY, Habibi E, Goncalves LG, Mesquita I, Cunha C, van Laarhoven A, van de Veerdonk FL, Williams DL, van der Meer JW, Logie C, O'Neill LA, Dinarello CA, Riksen NP, van Crevel R, Clish C, Notebaart RA, Joosten LA, Stunnenberg HG, Xavier RJ, Netea MG (2016) Glutaminolysis and fumarate accumulation integrate immunometabolic and epigenetic programs in trained immunity. Cell Metab. https://doi.org/ 10.1016/j.cmet.2016.10.008

Babula O, Lazdane G, Kroica J, Ledger WJ, Witkin SS (2003) Relation between recurrent vulvovaginal candidiasis, vaginal concentrations of mannose-binding lectin, and a 
mannose-binding lectin gene polymorphism in Latvian women. Clin Infect Dis 37(5):733-737. https://doi.org/10.1086/377234

Bekkering S, Arts RJW, Novakovic B, Kourtzelis I, van der Heijden C, Li Y, Popa CD, Ter Horst R, van Tuijl J, Netea-Maier RT, van de Veerdonk FL, Chavakis T, Joosten LAB, van der Meer JWM, Stunnenberg H, Riksen NP, Netea MG (2018) Metabolic induction of trained immunity through the mevalonate pathway. Cell 172(1-2):135-146(e139). https://doi.org/10. 1016/j.cell.2017.11.025

Bidula S, Schelenz S (2016) A sweet response to a sour situation: The role of soluble pattern recognition receptors in the innate immune response to invasive Aspergillus fumigatus Infections. PLoS Pathog 12(7):e1005637. https://doi.org/10.1371/journal.ppat.1005637

Bochud PY, Chien JW, Marr KA, Leisenring WM, Upton A, Janer M, Rodrigues SD, Li S, Hansen JA, Zhao LP, Aderem A, Boeckh M (2008) Toll-like receptor 4 polymorphisms and aspergillosis in stem-cell transplantation. The New England J Med 359(17):1766-1777. https:// doi.org/10.1056/NEJMoa0802629

Borghi M, De Luca A, Puccetti M, Jaeger M, Mencacci A, Oikonomou V, Pariano M, Garlanda C, Moretti S, Bartoli A, Sobel J, van de Veerdonk FL, Dinarello CA, Netea MG, Romani L (2015) Pathogenic NLRP3 inflammasome activity during Candida infection is negatively regulated by IL-22 via activation of NLRC4 and IL-1Ra. Cell Host Microbe 18(2):198-209. https://doi.org/ 10.1016/j.chom.2015.07.004

Bozza S, Campo S, Arseni B, Inforzato A, Ragnar L, Bottazzi B, Mantovani A, Moretti S, Oikonomous V, De Santis R, Carvalho A, Salvatori G, Romani L (2014) PTX3 binds MD-2 and promotes TRIF-dependent immune protection in aspergillosis. J Immunol 193(5):23402348. https://doi.org/10.4049/jimmunol.1400814

Brown GD, Denning DW, Gow NA, Levitz SM, Netea MG, White TC (2012) Hidden killers: human fungal infections. Sci Transl Med 4(165):165rv113. https://doi.org/10.1126/ scitranslmed.3004404

Brown GD, Gordon S (2001) Immune recognition. A new receptor for beta-glucans. Nature 413 (6851):36-37. https://doi.org/10.1038/35092620

Brown GD, Willment JA, Whitehead L (2018) C-type lectins in immunity and homeostasis. Nat Rev Immunol. https://doi.org/10.1038/s41577-018-0004-8

Caruso R, Warner N, Inohara N, Nunez G (2014) NOD1 and NOD2: signaling, host defense, and inflammatory disease. Immunity 41(6):898-908. https://doi.org/10.1016/j.immuni.2014.12.010

Carvalho A, Cunha C, Bistoni F, Romani L (2012a) Immunotherapy of aspergillosis. Clin Microbiol Infect: The Official Publ Eur Soc Clin Microbiol Infect Dis 18(2):120-125. https:// doi.org/10.1111/j.1469-0691.2011.03681.x

Carvalho A, Cunha C, Carotti A, Aloisi T, Guarrera O, Di Ianni M, Falzetti F, Bistoni F, Aversa F, Pitzurra L, Rodrigues F, Romani L (2009) Polymorphisms in toll-like receptor genes and susceptibility to infections in allogeneic stem cell transplantation. Exp Hematol 37(9):10221029. https://doi.org/10.1016/j.exphem.2009.06.004

Carvalho A, Cunha C, Pasqualotto AC, Pitzurra L, Denning DW, Romani L (2010) Genetic variability of innate immunity impacts human susceptibility to fungal diseases. Int J Infect Dis: IJID: Official Publ Int Soc Infect Dis 14(6):e460-468. https://doi.org/10.1016/j.ijid.2009.06. 028

Carvalho A, De Luca A, Bozza S, Cunha C, D'Angelo C, Moretti S, Perruccio K, Iannitti RG, Fallarino F, Pierini A, Latge JP, Velardi A, Aversa F, Romani L (2012b) TLR3 essentially promotes protective class I-restricted memory $\mathrm{CD} 8(+)$ T-cell responses to Aspergillus fumigatus in hematopoietic transplanted patients. Blood 119(4):967-977. https://doi.org/10. 1182/blood-2011-06-362582

Carvalho A, Giovannini G, De Luca A, D'Angelo C, Casagrande A, Iannitti RG, Ricci G, Cunha C, Romani L (2012c) Dectin-1 isoforms contribute to distinct Th1/Th17 cell activation in mucosal candidiasis. Cell Mol Immunol 9(3):276-286. https://doi.org/10.1038/cmi.2012.1

Carvalho A, Pasqualotto AC, Pitzurra L, Romani L, Denning DW, Rodrigues F (2008) Polymorphisms in toll-like receptor genes and susceptibility to pulmonary aspergillosis. J Infect Dis 197(4):618-621. https://doi.org/10.1086/526500 
Casadevall A (2018) Melanin triggers antifungal defences. Nature 555(7696):319-320. https://doi. org/10.1038/d41586-018-02370-x

Chai LY, de Boer MG, van der Velden WJ, Plantinga TS, van Spriel AB, Jacobs C, Halkes CJ, Vonk AG, Blijlevens NM, van Dissel JT, Donnelly PJ, Kullberg BJ, Maertens J, Netea MG (2011) The Y238X stop codon polymorphism in the human beta-glucan receptor dectin-1 and susceptibility to invasive aspergillosis. J Infect Dis 203(5):736-743. https://doi.org/10.1093/ infdis/jiq102

Cheng SC, Quintin J, Cramer RA, Shepardson KM, Saeed S, Kumar V, Giamarellos-Bourboulis EJ, Martens JH, Rao NA, Aghajanirefah A, Manjeri GR, Li Y, Ifrim DC, Arts RJ, van der Veer BM, Deen PM, Logie C, O'Neill LA, Willems P, van de Veerdonk FL, van der Meer JW, Ng A, Joosten LA, Wijmenga C, Stunnenberg HG, Xavier RJ, Netea MG (2014) mTOR- and HIF-1alpha-mediated aerobic glycolysis as metabolic basis for trained immunity. Science 345 (6204):1250684. https://doi.org/10.1126/science.1250684

Cheng SC, van de Veerdonk FL, Lenardon M, Stoffels M, Plantinga T, Smeekens S, Rizzetto L, Mukaremera L, Preechasuth K, Cavalieri D, Kanneganti TD, van der Meer JW, Kullberg BJ, Joosten LA, Gow NA, Netea MG (2011) The dectin-1/inflammasome pathway is responsible for the induction of protective T-helper 17 responses that discriminate between yeasts and hyphae of Candida albicans. J Leukoc Biol 90(2):357-366. https://doi.org/10.1189/jlb. 1210702

Chiarini M, Sabelli C, Melotti P, Garlanda C, Savoldi G, Mazza C, Padoan R, Plebani A, Mantovani A, Notarangelo LD, Assael BM, Badolato R (2010) PTX3 genetic variations affect the risk of Pseudomonas aeruginosa airway colonization in cystic fibrosis patients. Genes Immun 11(8):665-670. https://doi.org/10.1038/gene.2010.41

Chorny A, Casas-Recasens S, Sintes J, Shan M, Polentarutti N, Garcia-Escudero R, Walland AC, Yeiser JR, Cassis L, Carrillo J, Puga I, Cunha C, Bastos H, Rodrigues F, Lacerda JF, Morais A, Dieguez-Gonzalez R, Heeger PS, Salvatori G, Carvalho A, Garcia-Sastre A, Blander JM, Mantovani A, Garlanda C, Cerutti A (2016) The soluble pattern recognition receptor PTX3 links humoral innate and adaptive immune responses by helping marginal zone B cells. J Exp Med 213(10):2167-2185. https://doi.org/10.1084/jem.20150282

Cohen J, Vincent JL, Adhikari NK, Machado FR, Angus DC, Calandra T, Jaton K, Giulieri S, Delaloye J, Opal S, Tracey K, van der Poll T, Pelfrene E (2015) Sepsis: a roadmap for future research. Lancet Infect Dis 15(5):581-614. https://doi.org/10.1016/S1473-3099(15)70112-X

Crosdale DJ, Poulton KV, Ollier WE, Thomson W, Denning DW (2001) Mannose-binding lectin gene polymorphisms as a susceptibility factor for chronic necrotizing pulmonary aspergillosis. J Infect Dis 184(5):653-656. https://doi.org/10.1086/322791

Cunha C, Aversa F, Bistoni G, Casagrande A, Rodrigues F, Romani L, Carvalho A (2011a) Immunogenetic profiling to predict risk of invasive fungal diseases: where are we now? Immunol Invest 40(7-8):723-734. https://doi.org/10.3109/08820139.2011.586395

Cunha C, Aversa F, Lacerda JF, Busca A, Kurzai O, Grube M, Loffler J, Maertens JA, Bell AS, Inforzato A, Barbati E, Almeida B, Santos e Sousa P, Barbui A, Potenza L, Caira M, Rodrigues F, Salvatori G, Pagano L, Luppi M, Mantovani A, Velardi A, Romani L, Carvalho A (2014) Genetic PTX3 deficiency and aspergillosis in stem-cell transplantation. The New England J Med 370(5):421-432. https://doi.org/10.1056/nejmoa1211161

Cunha C, Aversa F, Romani L, Carvalho A (2013) Human genetic susceptibility to invasive aspergillosis. PLoS Pathog 9(8):e1003434. https://doi.org/10.1371/journal.ppat.1003434

Cunha C, Carvalho A (2012) Host genetics and invasive fungal diseases: towards improved diagnosis and therapy? Expert Rev Anti-infect Ther 10(3):257-259. https://doi.org/10.1586/eri. 12.3

Cunha C, Carvalho A (2018) Toward the identification of a genetic risk signature for pulmonary aspergillosis in chronic obstructive pulmonary disease. Clin Infect Dis 66(7):1153-1154. https://doi.org/10.1093/cid/cix944

Cunha C, Carvalho A, Esposito A, Bistoni F, Romani L (2012) DAMP signaling in fungal infections and diseases. Front Immunol 3:286. https://doi.org/10.3389/fimmu.2012.00286 
Cunha C, Di Ianni M, Bozza S, Giovannini G, Zagarella S, Zelante T, D’Angelo C, Pierini A, Pitzurra L, Falzetti F, Carotti A, Perruccio K, Latge JP, Rodrigues F, Velardi A, Aversa F, Romani L, Carvalho A (2010a) Dectin-1 Y238X polymorphism associates with susceptibility to invasive aspergillosis in hematopoietic transplantation through impairment of both recipientand donor-dependent mechanisms of antifungal immunity. Blood 116(24):5394-5402. https:// doi.org/10.1182/blood-2010-04-279307

Cunha C, Goncalves SM, Duarte-Oliveira C, Leite L, Lagrou K, Marques A, Lupianez CB, Mesquita I, Gaifem J, Barbosa AM, Pinho Vaz C, Branca R, Campilho F, Freitas F, Ligeiro D, Lass-Florl C, Loffler J, Jurado M, Saraiva M, Kurzai O, Rodrigues F, Castro AG, Silvestre R, Sainz J, Maertens JA, Torrado E, Jacobsen ID, Lacerda JF, Campos A Jr, Carvalho A (2017) IL-10 overexpression predisposes to invasive aspergillosis by suppressing antifungal immunity. J Allergy Clin Immunol. https://doi.org/10.1016/j.jaci.2017.02.034

Cunha C, Monteiro AA, Oliveira-Coelho A, Kuhne J, Rodrigues F, Sasaki SD, Schio SM, Camargo JJ, Mantovani A, Carvalho A, Pasqualotto AC (2015) PTX3-based genetic testing for risk of aspergillosis after lung transplant. Clin Infect Dis 61(12):1893-1894. https://doi.org/10. 1093/cid/civ679

Cunha C, Rodrigues F, Zelante T, Aversa F, Romani L, Carvalho A (2011b) Genetic susceptibility to aspergillosis in allogeneic stem-cell transplantation. Med Mycol 49(Suppl 1):S137-143. https://doi.org/10.3109/13693786.2010.508797

Cunha C, Romani L, Carvalho A (2010b) Cracking the toll-like receptor code in fungal infections. Expert Rev Anti-infect Ther 8(10):1121-1137. https://doi.org/10.1586/eri.10.93

Dambuza IM, Brown GD (2015) C-type lectins in immunity: recent developments. Curr Opin Immunol 32:21-27. https://doi.org/10.1016/j.coi.2014.12.002

Damiens S, Poissy J, Francois N, Salleron J, Jawhara S, Jouault T, Poulain D, Sendid B (2012) Mannose-binding lectin levels and variation during invasive candidiasis. J Clin Immunol 32 (6):1317-1323. https://doi.org/10.1007/s10875-012-9748-2

de Boer MG, Jolink H, Halkes CJ, van der Heiden PL, Kremer D, Falkenburg JH, van de Vosse E, van Dissel JT (2011) Influence of polymorphisms in innate immunity genes on susceptibility to invasive aspergillosis after stem cell transplantation. PLoS ONE 6(4):e18403. https://doi.org/ 10.1371/journal.pone.0018403

De Luca A, Carvalho A, Cunha C, Iannitti RG, Pitzurra L, Giovannini G, Mencacci A, Bartolommei L, Moretti S, Massi-Benedetti C, Fuchs D, De Bernardis F, Puccetti P, Romani L (2013) IL-22 and IDO1 affect immunity and tolerance to murine and human vaginal candidiasis. PLoS Pathog 9(7):e1003486. https://doi.org/10.1371/journal.ppat.1003486

Dix A, Vlaic S, Guthke R, Linde J (2016) Use of systems biology to decipher host-pathogen interaction networks and predict biomarkers. Clin Microbiol Infect: The Official Publ Eur Soc Clin Microbiol Infect Dis 22(7):600-606. https://doi.org/10.1016/j.cmi.2016.04.014

Donders GG, Babula O, Bellen G, Linhares IM, Witkin SS (2008) Mannose-binding lectin gene polymorphism and resistance to therapy in women with recurrent vulvovaginal candidiasis. BJOG 115(10):1225-1231. https://doi.org/10.1111/j.1471-0528.2008.01830.x

Durrant C, Tayem H, Yalcin B, Cleak J, Goodstadt L, de Villena FP, Mott R, Iraqi FA (2011) Collaborative cross mice and their power to map host susceptibility to Aspergillus fumigatus infection. Genome Res 21(8):1239-1248. https://doi.org/10.1101/gr.118786.110

Ferwerda B, Ferwerda G, Plantinga TS, Willment JA, van Spriel AB, Venselaar H, Elbers CC, Johnson MD, Cambi A, Huysamen C, Jacobs L, Jansen T, Verheijen K, Masthoff L, Morre SA, Vriend G, Williams DL, Perfect JR, Joosten LA, Wijmenga C, van der Meer JW, Adema GJ, Kullberg BJ, Brown GD, Netea MG (2009) Human dectin-1 deficiency and mucocutaneous fungal infections. The New England J Med 361(18):1760-1767. https://doi.org/10.1056/ NEJMoa0901053

Fischer M, Muller JP, Spies-Weisshart B, Grafe C, Kurzai O, Hunniger K, Hochhaus A, Scholl S, Schnetzke U (2017) Isoform localization of Dectin-1 regulates the signaling quality of anti-fungal immunity. Eur J Immunol 47(5):848-859. https://doi.org/10.1002/eji.201646849

Fischer M, Spies-Weisshart B, Schrenk K, Gruhn B, Wittig S, Glaser A, Hochhaus A, Scholl S, Schnetzke U (2016) Polymorphisms of Dectin-1 and TLR2 predispose to invasive fungal 
disease in patients with acute myeloid leukemia. PLoS ONE 11(3):e0150632. https://doi.org/ 10.1371/journal.pone.0150632

Fisher CE, Hohl TM, Fan W, Storer BE, Levine DM, Zhao LP, Martin PJ, Warren EH, Boeckh M, Hansen JA (2017) Validation of single nucleotide polymorphisms in invasive aspergillosis following hematopoietic cell transplantation. Blood 129(19):2693-2701. https://doi.org/10. 1182/blood-2016-10-743294

Foo SS, Reading PC, Jaillon S, Mantovani A, Mahalingam S (2015) Pentraxins and collectins: friend or foe during pathogen invasion? Trends Microbiol 23(12):799-811. https://doi.org/10. 1016/j.tim.2015.09.006

Garlanda C, Hirsch E, Bozza S, Salustri A, De Acetis M, Nota R, Maccagno A, Riva F, Bottazzi B, Peri G, Doni A, Vago L, Botto M, De Santis R, Carminati P, Siracusa G, Altruda F, Vecchi A, Romani L, Mantovani A (2002) Non-redundant role of the long pentraxin PTX3 in anti-fungal innate immune response. Nature 420(6912):182-186. https://doi.org/10.1038/nature01195

Gazendam RP, van Hamme JL, Tool AT, van Houdt M, Verkuijlen PJ, Herbst M, Liese JG, van de Veerdonk FL, Roos D, van den Berg TK, Kuijpers TW (2014) Two independent killing mechanisms of Candida albicans by human neutrophils: evidence from innate immunity defects. Blood 124(4):590-597. https://doi.org/10.1182/blood-2014-01-551473

Geijtenbeek TB, Gringhuis SI (2009) Signalling through C-type lectin receptors: shaping immune responses. Nat Rev Immunol 9(7):465-479

Giraldo PC, Babula O, Goncalves AK, Linhares IM, Amaral RL, Ledger WJ, Witkin SS (2007) Mannose-binding lectin gene polymorphism, vulvovaginal candidiasis, and bacterial vaginosis. Obstet Gynecol 109(5):1123-1128. https://doi.org/10.1097/01.AOG.0000260386.17555.a5

Glocker EO, Hennigs A, Nabavi M, Schaffer AA, Woellner C, Salzer U, Pfeifer D, Veelken H, Warnatz K, Tahami F, Jamal S, Manguiat A, Rezaei N, Amirzargar AA, Plebani A, Hannesschlager N, Gross O, Ruland J, Grimbacher B (2009) A homozygous CARD9 mutation in a family with susceptibility to fungal infections. The New England J Med 361(18):17271735. https://doi.org/10.1056/NEJMoa0810719

Gonçalves SM, Lagrou K, Rodrigues CS, Campos CF, Bernal-Martínez L, Rodrigues F, Silvestre R, Alcazar-Fuoli L, Maertens JA, Cunha C, Carvalho A (2017) Evaluation of bronchoalveolar lavage fluid cytokines as biomarkers for invasive pulmonary aspergillosis in at-risk patients. Front Microbiol 8:2362. https://doi.org/10.3389/fmicb.2017.02362

Gow NA, Hube B (2012) Importance of the Candida albicans cell wall during commensalism and infection. Curr Opin Microbiol 15(4):406-412. https://doi.org/10.1016/j.mib.2012.04.005

Gresnigt MS, Cunha C, Jaeger M, Gonçalves SM, Subbarao Malireddi RK, Ammerdorfer A, Lubbers R, Oosting M, Rasid O, Jouvion G, Fitting C, De Jong D, Lacerda JF, Campos Jr A, Melchers WJ, Lagrou K, Maertens J, Kanneganti TD, Carvalho A, Ibrahim-Granet O, Van de Veerdonk FL (2018) Genetic deficiency of NOD2 confers resistance to invasive aspergillosis. Nat Commun; PMID: 29980664, https://doi.org/10.1038/s41467-018-04912-3

Gresnigt MS, Jaeger M, Subbarao Malireddi RK, Rasid O, Jouvion G, Fitting C, Melchers WJG, Kanneganti TD, Carvalho A, Ibrahim-Granet O, van de Veerdonk FL (2017) The absence of NOD1 enhances killing of Aspergillus fumigatus through modulation of Dectin-1 expression. Front Immunol 8:1777. https://doi.org/10.3389/fimmu.2017.01777

Grimm MJ, Vethanayagam RR, Almyroudis NG, Dennis CG, Khan AN, D’Auria AC, Singel KL, Davidson BA, Knight PR, Blackwell TS, Hohl TM, Mansour MK, Vyas JM, Rohm M, Urban CF, Kelkka T, Holmdahl R, Segal BH (2013) Monocyte- and macrophage-targeted NADPH oxidase mediates antifungal host defense and regulation of acute inflammation in mice. J Immunol 190(8):4175-4184. https://doi.org/10.4049/jimmunol.1202800

Grube M, Loeffler J, Mezger M, Kruger B, Echtenacher B, Hoffmann P, Edinger M, Einsele H, Andreesen R, Holler E (2013) TLR5 stop codon polymorphism is associated with invasive aspergillosis after allogeneic stem cell transplantation. Med Mycol 51(8):818-825. https://doi. org/10.3109/13693786.2013.809630

Hawn TR, Verbon A, Lettinga KD, Zhao LP, Li SS, Laws RJ, Skerrett SJ, Beutler B, Schroeder L, Nachman A, Ozinsky A, Smith KD, Aderem A (2003) A common dominant TLR5 stop codon 
polymorphism abolishes flagellin signaling and is associated with susceptibility to legionnaires' disease. J Exp Med 198(10):1563-1572. https://doi.org/10.1084/jem.20031220

Hayashi F, Smith KD, Ozinsky A, Hawn TR, Yi EC, Goodlett DR, Eng JK, Akira S, Underhill DM, Aderem A (2001) The innate immune response to bacterial flagellin is mediated by toll-like receptor 5. Nature 410(6832):1099-1103. https://doi.org/10.1038/35074106

He Q, Li H, Rui Y, Liu L, He B, Shi Y, Su X (2018) Pentraxin 3 gene polymorphisms and pulmonary aspergillosis in chronic obstructive pulmonary disease patients. Clin Infect Dis 66 (2):261-267. https://doi.org/10.1093/cid/cix749

Hise AG, Tomalka J, Ganesan S, Patel K, Hall BA, Brown GD, Fitzgerald KA (2009) An essential role for the NLRP3 inflammasome in host defense against the human fungal pathogen Candida albicans. Cell Host Microbe 5(5):487-497. https://doi.org/10.1016/j.chom.2009.05.002

Jaeger M, Carvalho A, Cunha C, Plantinga TS, van de Veerdonk F, Puccetti M, Galosi C, Joosten LA, Dupont B, Kullberg BJ, Sobel JD, Romani L, Netea MG (2016) Association of a variable number tandem repeat in the NLRP3 gene in women with susceptibility to RVVC. Eur J Clin Microbiol Infect Dis: Official Publ Eur Soc Clin Microbiol 35(5):797-801. https:// doi.org/10.1007/s10096-016-2600-5

Jaeger M, van der Lee R, Cheng SC, Johnson MD, Kumar V, Ng A, Plantinga TS, Smeekens SP, Oosting M, Wang X, Barchet W, Fitzgerald K, Joosten LAB, Perfect JR, Wijmenga C, van de Veerdonk FL, Huynen MA, Xavier RJ, Kullberg BJ, Netea MG (2015) The RIG-I-like helicase receptor MDA5 (IFIH1) is involved in the host defense against Candida infections. Eur J Clin Microbiol Infect Dis: Official Publ Eur Soc Clin Microbiol 34(5):963-974. https://doi.org/10. 1007/s10096-014-2309-2

Jaillon S, Moalli F, Ragnarsdottir B, Bonavita E, Puthia M, Riva F, Barbati E, Nebuloni M, Cvetko Krajinovic L, Markotic A, Valentino S, Doni A, Tartari S, Graziani G, Montanelli A, Delneste Y, Svanborg C, Garlanda C, Mantovani A (2014) The humoral pattern recognition molecule PTX3 is a key component of innate immunity against urinary tract infection. Immunity 40(4):621-632. https://doi.org/10.1016/j.immuni.2014.02.015

Johnson CM, Lyle EA, Omueti KO, Stepensky VA, Yegin O, Alpsoy E, Hamann L, Schumann RR, Tapping RI (2007) Cutting edge: a common polymorphism impairs cell surface trafficking and functional responses of TLR1 but protects against leprosy. J Immunol 178(12):7520-7524

Johnson MD, Plantinga TS, van de Vosse E, Velez Edwards DR, Smith PB, Alexander BD, Yang JC, Kremer D, Laird GM, Oosting M, Joosten LA, van der Meer JW, van Dissel JT, Walsh TJ, Perfect JR, Kullberg BJ, Scott WK, Netea MG (2012) Cytokine gene polymorphisms and the outcome of invasive candidiasis: a prospective cohort study. Clin Infect Dis 54(4):502-510. https://doi.org/10.1093/cid/cir827

Karki R, Man SM, Malireddi RK, Gurung P, Vogel P, Lamkanfi M, Kanneganti TD (2015) Concerted activation of the AIM2 and NLRP3 inflammasomes orchestrates host protection against Aspergillus infection. Cell Host Microbe 17(3):357-368. https://doi.org/10.1016/j. chom.2015.01.006

Kesh S, Mensah NY, Peterlongo P, Jaffe D, Hsu K, M VDB, O'Reilly R, Pamer E, Satagopan J, Papanicolaou GA (2005) TLR1 and TLR6 polymorphisms are associated with susceptibility to invasive aspergillosis after allogeneic stem cell transplantation. Ann New York Acad Sci 1062:95-103. https://doi.org/10.1196/annals.1358.012

Koehler FC, Cornely OA, Wisplinghoff H, Chang DH, Richter A, Koehler P (2018) Candidareactive $\mathrm{T}$ cells for the diagnosis of invasive Candida infection of the lumbar vertebral spine. Mycoses 61(1):48-52. https://doi.org/10.1111/myc.12696

Koldehoff M, Beelen DW, Elmaagacli AH (2013) Increased susceptibility for aspergillosis and post-transplant immune deficiency in patients with gene variants of TLR4 after stem cell transplantation. Transplant Infect Dis: An Official J Transplant Soc 15(5):533-539. https://doi. org/10.1111/tid.12115

Kumar V, Cheng SC, Johnson MD, Smeekens SP, Wojtowicz A, Giamarellos-Bourboulis E, Karjalainen J, Franke L, Withoff S, Plantinga TS, van de Veerdonk FL, van der Meer JW, Joosten LA, Sokol H, Bauer H, Herrmann BG, Bochud PY, Marchetti O, Perfect JR, 
Xavier RJ, Kullberg BJ, Wijmenga C, Netea MG (2014) Immunochip SNP array identifies novel genetic variants conferring susceptibility to candidaemia. Nature Commun 5:4675. https://doi.org/10.1038/ncomms5675

Kyrmizi I, Gresnigt MS, Akoumianaki T, Samonis G, Sidiropoulos P, Boumpas D, Netea MG, van de Veerdonk FL, Kontoyiannis DP, Chamilos G (2013) Corticosteroids block autophagy protein recruitment in Aspergillus fumigatus phagosomes via targeting dectin-1/Syk kinase signaling. J Immunol 191(3):1287-1299. https://doi.org/10.4049/jimmunol.1300132

Lambourne J, Agranoff D, Herbrecht R, Troke PF, Buchbinder A, Willis F, Letscher-Bru V, Agrawal S, Doffman S, Johnson E, White PL, Barnes RA, Griffin G, Lindsay JA, Harrison TS (2009) Association of mannose-binding lectin deficiency with acute invasive aspergillosis in immunocompromised patients. Clin Infect Dis 49(10):1486-1491. https://doi.org/10.1086/ 644619

Latge JP, Beauvais A, Chamilos G (2017) The cell wall of the human fungal pathogen Aspergillus fumigatus: biosynthesis, organization, immune response, and virulence. Annu Rev Microbiol 71:99-116. https://doi.org/10.1146/annurev-micro-030117-020406

Lemaitre B, Nicolas E, Michaut L, Reichhart JM, Hoffmann JA (1996) The dorsoventral regulatory gene cassette spatzle/Toll/cactus controls the potent antifungal response in Drosophila adults. Cell 86(6):973-983

Lev-Sagie A, Prus D, Linhares IM, Lavy Y, Ledger WJ, Witkin SS (2009) Polymorphism in a gene coding for the inflammasome component NALP3 and recurrent vulvovaginal candidiasis in women with vulvar vestibulitis syndrome. Am J Obstet Gynecol 200(3):303(e301-306). https://doi.org/10.1016/j.ajog.2008.10.039

Li Y, Oosting M, Deelen P, Ricano-Ponce I, Smeekens S, Jaeger M, Matzaraki V, Swertz MA, Xavier RJ, Franke L, Wijmenga C, Joosten LA, Kumar V, Netea MG (2016a) Inter-individual variability and genetic influences on cytokine responses to bacteria and fungi. Nat Med 22 (8):952-960. https://doi.org/10.1038/nm.4139

Li Y, Oosting M, Smeekens SP, Jaeger M, Aguirre-Gamboa R, Le KT, Deelen P, Ricano-Ponce I, Schoffelen T, Jansen AF, Swertz MA, Withoff S, van de Vosse E, van Deuren M, van de Veerdonk F, Zhernakova A, van der Meer JW, Xavier RJ, Franke L, Joosten LA, Wijmenga C, Kumar V, Netea MG (2016b) A functional genomics approach to understand variation in cytokine production in humans. Cell 167(4):1099-1110(e1014). https://doi.org/10.1016/j.cell. 2016.10.017

Lionakis MS, Levitz SM (2017) Host control of fungal infections: lessons from basic studies and human cohorts. Annu Rev Immunol. https://doi.org/10.1146/annurev-immunol-042617053318

Lionakis MS, Levitz SM (2018) Host control of fungal infections: lessons from basic studies and human cohorts. Annu Rev Immunol 36:157-191. https://doi.org/10.1146/annurev-immunol042617-053318

Lo Giudice P, Campo S, De Santis R, Salvatori G (2012) Effect of PTX3 and voriconazole combination in a rat model of invasive pulmonary aspergillosis. Antimicrob Agents Chemother 56(12):6400-6402. https://doi.org/10.1128/AAC.01000-12

Marra E, Sousa VL, Gaziano R, Pacello ML, Arseni B, Aurisicchio L, De Santis R, Salvatori G (2014) Efficacy of PTX3 and posaconazole combination in a rat model of invasive pulmonary aspergillosis. Antimicrob Agents Chemother 58(10):6284-6286. https://doi.org/10.1128/AAC. 03038-14

Mauri T, Coppadoro A, Bombino M, Bellani G, Zambelli V, Fornari C, Berra L, Bittner EA, Schmidt U, Sironi M, Bottazzi B, Brambilla P, Mantovani A, Pesenti A (2014) Alveolar pentraxin 3 as an early marker of microbiologically confirmed pneumonia: a threshold-finding prospective observational study. Crit Care 18(5):562. https://doi.org/10.1186/s13054-0140562-5

Nahum A, Dadi H, Bates A, Roifman CM (2011) The L412F variant of Toll-like receptor 3 (TLR3) is associated with cutaneous candidiasis, increased susceptibility to cytomegalovirus, and autoimmunity. J Allergy Clin Immunol 127(2):528-531. https://doi.org/10.1016/j.jaci. 2010.09.031 
Nedovic B, Posteraro B, Leoncini E, Ruggeri A, Amore R, Sanguinetti M, Ricciardi W, Boccia S (2014) Mannose-binding lectin codon 54 gene polymorphism and vulvovaginal candidiasis: a systematic review and meta-analysis. Biomed Res Int 2014:738298. https://doi.org/10.1155/ 2014/738298

Netea MG, Joosten LA, van der Meer JW, Kullberg BJ, van de Veerdonk FL (2015) Immune defence against Candida fungal infections. Nat Rev Immunol 15(10):630-642. https://doi.org/ $10.1038 /$ nri3897

Netea MG, van der Meer JW (2017) Trained immunity: an ancient way of remembering. Cell Host Microbe 21(3):297-300. https://doi.org/10.1016/j.chom.2017.02.003

Netea MG, Wijmenga C, O'Neill LA (2012) Genetic variation in toll-like receptors and disease susceptibility. Nat Immunol 13(6):535-542. https://doi.org/10.1038/ni.2284

Oliveira-Coelho A, Rodrigues F, Campos A Jr, Lacerda JF, Carvalho A, Cunha C (2015) Paving the way for predictive diagnostics and personalized treatment of invasive aspergillosis. Front Microbiol 6:411. https://doi.org/10.3389/fmicb.2015.00411

Overton NL, Simpson A, Bowyer P, Denning DW (2017) Genetic susceptibility to severe asthma with fungal sensitization. Int J Immunogenet 44(3):93-106. https://doi.org/10.1111/iji.12312

Patin EC, Thompson A, Orr SJ (2018) Pattern recognition receptors in fungal immunity. Semin Cell Dev Biol. https://doi.org/10.1016/j.semcdb.2018.03.003

Pfaller MA, Diekema DJ (2010) Epidemiology of invasive mycoses in North America. Crit Rev Microbiol 36(1):1-53. https://doi.org/10.3109/10408410903241444

Plantinga TS, Hamza OJ, Willment JA, Ferwerda B, van de Geer NM, Verweij PE, Matee MI, Banahan K, O’Neill LA, Kullberg BJ, Brown GD, van der Ven AJ, Netea MG (2010) Genetic variation of innate immune genes in HIV-infected african patients with or without oropharyngeal candidiasis. J Acquir Immune Defic Syndr 55(1):87-94. https://doi.org/10. 1097/QAI.0b013e3181e53c64

Plantinga TS, Johnson MD, Scott WK, van de Vosse E, Velez Edwards DR, Smith PB, Alexander BD, Yang JC, Kremer D, Laird GM, Oosting M, Joosten LA, van der Meer JW, van Dissel JT, Walsh TJ, Perfect JR, Kullberg BJ, Netea MG (2012) Toll-like receptor 1 polymorphisms increase susceptibility to candidemia. J Infect Dis 205(6):934-943. https://doi. org/10.1093/infdis/jir867

Plantinga TS, van der Velden WJ, Ferwerda B, van Spriel AB, Adema G, Feuth T, Donnelly JP, Brown GD, Kullberg BJ, Blijlevens NM, Netea MG (2009) Early stop polymorphism in human DECTIN-1 is associated with increased Candida colonization in hematopoietic stem cell transplant recipients. Clin Infect Dis 49(5):724-732. https://doi.org/10.1086/604714

Potenza L, Vallerini D, Barozzi P, Riva G, Forghieri F, Beauvais A, Beau R, Candoni A, Maertens J, Rossi G, Morselli M, Zanetti E, Quadrelli C, Codeluppi M, Guaraldi G, Pagano L, Caira M, Del Giovane C, Maccaferri M, Stefani A, Morandi U, Tazzioli G, Girardis M, Delia M, Specchia G, Longo G, Marasca R, Narni F, Merli F, Imovilli A, Apolone G, Carvalho A, Comoli P, Romani L, Latge JP, Luppi M (2013) Characterization of specific immune responses to different Aspergillus antigens during the course of invasive aspergillosis in hematologic patients. PLoS ONE 8(9):e74326. https://doi.org/10.1371/journal.pone. 0074326

Puel A, Doffinger R, Natividad A, Chrabieh M, Barcenas-Morales G, Picard C, Cobat A, Ouachee-Chardin M, Toulon A, Bustamante J, Al-Muhsen S, Al-Owain M, Arkwright PD, Costigan C, McConnell V, Cant AJ, Abinun M, Polak M, Bougneres PF, Kumararatne D, Marodi L, Nahum A, Roifman C, Blanche S, Fischer A, Bodemer C, Abel L, Lilic D, Casanova JL (2010) Autoantibodies against IL-17A, IL-17F, and IL-22 in patients with chronic mucocutaneous candidiasis and autoimmune polyendocrine syndrome type I. J Exp Med 207 (2):291-297. https://doi.org/10.1084/jem.20091983

Quach H, Wilson D, Laval G, Patin E, Manry J, Guibert J, Barreiro LB, Nerrienet E, Verschoor E, Gessain A, Przeworski M, Quintana-Murci L (2013) Different selective pressures shape the evolution of toll-like receptors in human and African great ape populations. Hum Mol Genet 22 (23):4829-4840. https://doi.org/10.1093/hmg/ddt335 
Radovanovic I, Mullick A, Gros P (2011) Genetic control of susceptibility to infection with Candida albicans in mice. PLoS ONE 6(4):e18957. https://doi.org/10.1371/journal.pone. 0018957

Rello J, van Engelen TSR, Alp E, Calandra T, Cattoir V, Kern WV, Netea MG, Nseir S, Opal SM, van de Veerdonk FL, Wilcox MH, Wiersinga WJ (2018) Towards precision medicine in sepsis: a position paper from the European society of clinical microbiology and infectious diseases. Clin Microbiol Infect: The Official Publ Eur Soc Clin Microbiol Infect Dis. https://doi.org/10. 1016/j.cmi.2018.03.011

Rieber N, Gazendam RP, Freeman AF, Hsu AP, Collar AL, Sugui JA, Drummond RA, Rongkavilit C, Hoffman K, Henderson C, Clark L, Mezger M, Swamydas M, Engeholm M, Schule R, Neumayer B, Ebel F, Mikelis CM, Pittaluga S, Prasad VK, Singh A, Milner JD, Williams KW, Lim JK, Kwon-Chung KJ, Holland SM, Hartl D, Kuijpers TW, Lionakis MS (2016) Extrapulmonary Aspergillus infection in patients with CARD9 deficiency. JCI Insight 1 (17):e89890. https://doi.org/10.1172/jci.insight.89890

Rock FL, Hardiman G, Timans JC, Kastelein RA, Bazan JF (1998) A family of human receptors structurally related to Drosophila Toll. Proc Natl Acad Sci USA 95(2):588-593

Rosentul DC, Delsing CE, Jaeger M, Plantinga TS, Oosting M, Costantini I, Venselaar H, Joosten LA, van der Meer JW, Dupont B, Kullberg BJ, Sobel JD, Netea MG (2014) Gene polymorphisms in pattern recognition receptors and susceptibility to idiopathic recurrent vulvovaginal candidiasis. Front Microbiol 5:483. https://doi.org/10.3389/fmicb.2014.00483

Rubino I, Coste A, Le Roy D, Roger T, Jaton K, Boeckh M, Monod M, Latge JP, Calandra T, Bochud PY (2012) Species-specific recognition of Aspergillus fumigatus by toll-like receptor 1 and toll-like receptor 6. J Infect Dis 205(6):944-954. https://doi.org/10.1093/infdis/jir882

Said-Sadier N, Padilla E, Langsley G, Ojcius DM (2010) Aspergillus fumigatus stimulates the NLRP3 inflammasome through a pathway requiring ROS production and the Syk tyrosine kinase. PLoS ONE 5(4):e10008. https://doi.org/10.1371/journal.pone.0010008

Sainz J, Lupianez CB, Segura-Catena J, Vazquez L, Rios R, Oyonarte S, Hemminki K, Forsti A, Jurado M (2012) Dectin-1 and DC-SIGN polymorphisms associated with invasive pulmonary aspergillosis infection. PLoS ONE 7(2):e32273. https://doi.org/10.1371/journal.pone.0032273

Salazar F, Brown GD (2018) Antifungal innate immunity: a perspective from the last 10 years. J Innate Immun 1-25. https://doi.org/10.1159/000488539

Smeekens SP, Ng A, Kumar V, Johnson MD, Plantinga TS, van Diemen C, Arts P, Verwiel ET, Gresnigt MS, Fransen K, van Sommeren S, Oosting M, Cheng SC, Joosten LA, Hoischen A, Kullberg BJ, Scott WK, Perfect JR, van der Meer JW, Wijmenga C, Netea MG, Xavier RJ (2013a) Functional genomics identifies type I interferon pathway as central for host defense against Candida albicans. Nat Commun 4:1342. https://doi.org/10.1038/ncomms2343

Smeekens SP, van de Veerdonk FL, Kullberg BJ, Netea MG (2013b) Genetic susceptibility to Candida infections. EMBO Mol Med 5(6):805-813. https://doi.org/10.1002/emmm. 201201678

Sprong T, van Deuren M (2008) Mannose-binding lectin: ancient molecule, interesting future. Clin Infect Dis 47(4):517-518. https://doi.org/10.1086/590007

Stappers MHT, Clark AE, Aimanianda V, Bidula S, Reid DM, Asamaphan P, Hardison SE, Dambuza IM, Valsecchi I, Kerscher B, Plato A, Wallace CA, Yuecel R, Hebecker B, da Gloria Teixeira Sousa M, Cunha C, Liu Y, Feizi T, Brakhage AA, Kwon-Chung KJ, Gow NAR, Zanda M, Piras M, Zanato C, Jaeger M, Netea MG, van de Veerdonk FL, Lacerda JF, Campos A, Carvalho A, Willment JA, Latge JP, Brown GD (2018) Recognition of DHN-melanin by a C-type lectin receptor is required for immunity to Aspergillus. Nature 555 (7696):382-386. https://doi.org/10.1038/nature25974

Takeuchi O, Akira S (2010) Pattern recognition receptors and inflammation. Cell 140(6):805-820. https://doi.org/10.1016/j.cell.2010.01.022

Taylor PR, Tsoni SV, Willment JA, Dennehy KM, Rosas M, Findon H, Haynes K, Steele C, Botto M, Gordon S, Brown GD (2007) Dectin-1 is required for beta-glucan recognition and control of fungal infection. Nat Immunol 8(1):31-38. https://doi.org/10.1038/ni1408 
Tierney L, Linde J, Muller S, Brunke S, Molina JC, Hube B, Schock U, Guthke R, Kuchler K (2012) An interspecies regulatory network inferred from simultaneous RNA-seq of Candida albicans invading innate immune cells. Front Microbiol 3:85. https://doi.org/10.3389/fmicb. 2012.00085

Tomalka J, Ganesan S, Azodi E, Patel K, Majmudar P, Hall BA, Fitzgerald KA, Hise AG (2011) A novel role for the NLRC4 inflammasome in mucosal defenses against the fungal pathogen Candida albicans. PLoS Pathog 7(12):e1002379. https://doi.org/10.1371/journal.ppat.1002379 PPATHOGENS-D-11-00989 [pii]

Usluogullari B, Gumus I, Gunduz E, Kaygusuz I, Simavli S, Acar M, Oznur M, Gunduz M, Kafali H (2014) The role of human Dectin-1 Y238X gene polymorphism in recurrent vulvovaginal candidiasis infections. Mol Biol Rep 41(10):6763-6768. https://doi.org/10.1007/ s11033-014-3562-2

Vaid M, Kaur S, Sambatakou H, Madan T, Denning DW, Sarma PU (2007) Distinct alleles of mannose-binding lectin (MBL) and surfactant proteins A (SP-A) in patients with chronic cavitary pulmonary aspergillosis and allergic bronchopulmonary aspergillosis. Clin Chem Lab Med 45(2):183-186. https://doi.org/10.1515/CCLM.2007.033

van de Veerdonk FL, Gresnigt MS, Romani L, Netea MG, Latge JP (2017) Aspergillus fumigatus morphology and dynamic host interactions. Nat Rev Microbiol 15(11):661-674. https://doi. org/10.1038/nrmicro.2017.90

van de Veerdonk FL, Joosten LA, Netea MG (2015) The interplay between inflammasome activation and antifungal host defense. Immunol Rev 265(1):172-180. https://doi.org/10.1111/ imr. 12280

van der Velden WJ, Blijlevens NM, Donnelly JP (2011) Genetic variants and the risk for invasive mould disease in immunocompromised hematology patients. Curr Opin Infect Dis 24(6):554563. https://doi.org/10.1097/QCO.0b013e32834ab1f4

Wagener J, Malireddi RK, Lenardon MD, Koberle M, Vautier S, MacCallum DM, Biedermann T, Schaller M, Netea MG, Kanneganti TD, Brown GD, Brown AJ, Gow NA (2014) Fungal chitin dampens inflammation through IL-10 induction mediated by NOD2 and TLR9 activation. PLoS Pathog 10(4):e1004050. https://doi.org/10.1371/journal.ppat.1004050

White PL, Parr C, Barnes RA (2018) Predicting invasive aspergillosis in hematology patients by combining clinical and genetic risk factors with early diagnostic biomarkers. J Clin Microbiol 56(1). https://doi.org/10.1128/jcm.01122-17

Wlasiuk G, Khan S, Switzer WM, Nachman MW (2009) A history of recurrent positive selection at the toll-like receptor 5 in primates. Mol Biol Evol 26(4):937-949. https://doi.org/10.1093/ molbev/msp018

Wojitani MD, de Aguiar LM, Baracat EC, Linhares IM (2012) Association between mannose-binding lectin and interleukin-1 receptor antagonist gene polymorphisms and recurrent vulvovaginal candidiasis. Arch Gynecol Obstet 285(1):149-153. https://doi.org/10. 1007/s00404-011-1920-Z

Wojtowicz A, Bochud PY (2014) Host genetics of invasive Aspergillus and Candida infections. Semin Immunopathol. https://doi.org/10.1007/s00281-014-0468-y

Wojtowicz A, Lecompte TD, Bibert S, Manuel O, Rueger S, Berger C, Boggian K, Cusini A, Garzoni C, Hirsch H, Khanna N, Mueller NJ, Meylan PR, Pascual M, van Delden C, Bochud PY, Swiss Transplant Cohort S (2015) PTX3 polymorphisms and invasive mold infections after solid organ transplant. Clin Infect Dis 61(4):619-622. https://doi.org/10.1093/ cid/civ386

Wurfel MM, Gordon AC, Holden TD, Radella F, Strout J, Kajikawa O, Ruzinski JT, Rona G, Black RA, Stratton S, Jarvik GP, Hajjar AM, Nickerson DA, Rieder M, Sevransky J, Maloney JP, Moss M, Martin G, Shanholtz C, Garcia JG, Gao L, Brower R, Barnes KC, Walley KR, Russell JA, Martin TR (2008) Toll-like receptor 1 polymorphisms affect innate immune responses and outcomes in sepsis. Am J Respir Crit Care Med 178(7):710-720. https://doi.org/10.1164/rccm.200803-462OC

Xu X, Xu JF, Zheng G, Lu HW, Duan JL, Rui W, Guan JH, Cheng LQ, Yang DD, Wang MC, Lv QZ, Li JX, Zhao X, Chen CX, Shi P, Jia XM, Lin X (2018) CARD9(S12 N) facilitates the 
Host Genetic Signatures of Susceptibility to Fungal Disease

production of IL- 5 by alveolar macrophages for the induction of type 2 immune responses. Nat Immunol. https://doi.org/10.1038/s41590-018-0112-4

Zaas AK, Liao G, Chien JW, Weinberg C, Shore D, Giles SS, Marr KA, Usuka J, Burch LH, Perera L, Perfect JR, Peltz G, Schwartz DA (2008) Plasminogen alleles influence susceptibility to invasive aspergillosis. PLoS Genet 4(6):e1000101. https://doi.org/10.1371/journal.pgen. 1000101

Zhang SY, Herman M, Ciancanelli MJ, Perez de Diego R, Sancho-Shimizu V, Abel L, Casanova JL (2013) TLR3 immunity to infection in mice and humans. Curr Opin Immunol 25 (1):19-33. https://doi.org/10.1016/j.coi.2012.11.001 